\title{
Meningitis retention syndrome caused by varicella zoster virus in a patient without a rash: a case report
}

Tsuneaki Kenzaka ${ }^{1,2^{*}} \mathbb{D}$, Ken Goda $^{1,2}$ and Ayako Kumabe ${ }^{2}$

\begin{abstract}
Background: Meningitis retention syndrome (MRS) is a rare condition that presents with acute urinary retention as a complication of aseptic meningitis. Cases of MRS due to varicella zoster virus (VZV) infection without a rash are rare. We report the case of a patient who had no signs of meningitis or VZV infection, including a rash.

Case presentation: A 58-year-old man presented with dysesthesia of the lower limbs and acute urinary retention. He had fever but no rash and no signs of meningitis. He was diagnosed to have VZV infection based on the detection of VZV DNA in the cerebrospinal fluid. He responded satisfactorily to a course of intravenous acyclovir and experienced no sequelae during a 2-year follow-up period.

Conclusion: MRS due to aseptic meningitis of viral origin should be considered in the differential diagnosis of acute urinary retention even in the absence of specific signs and symptoms of meningitis or a suggestive rash.

Keywords: Meningitis retention syndrome, Varicella zoster virus, Zoster sine herpete, Acute urinary retention, Lower limb dysesthesia
\end{abstract}

\section{Background}

The usual causes of acute urinary retention in adults include prostatic hyperplasia, peripheral nerve diseases involving the sacral spinal cord, such as diabetic neuropathy and Guillain-Barré syndrome, and diseases of the lumbar spinal canal, such as lumbar spondylosis and lumbar disc herniation. However, acute urinary retention has also been reported in association with cerebral demyelinating diseases such as acute disseminated encephalomyelitis and multiple sclerosis, aseptic meningitis, and herpes in the sacral region [1]. Meningitis retention syndrome (MRS) is a rare condition associated with aseptic meningitis presenting with acute urinary retention [2]. Enteroviruses, flaviviruses, arboviruses, and

\footnotetext{
*Correspondence: smile.kenzaka@jichi.ac.jp

${ }^{1}$ Department of Internal Medicine, Hyogo Prefectural Tamba Medical Center, Tanba, Japan

Full list of author information is available at the end of the article
}

herpes simplex viruses are common viral causes of MRS, whereas varicella zoster virus (VZV) is rarely associated with MRS $[4,5]$.

A typical skin rash is not observed in about $40 \%$ of patients with meningoencephalitis caused by VZV [6]. However, besides fever, most patients with aseptic meningitis, including VZV meningitis, report symptoms such as headache, nausea and vomiting, signs of meningeal irritation, disturbance of consciousness, and brain dysfunction (cognitive dysfunction, behavioral changes, neurological symptoms, and convulsions) [7-9].

Here, we report about a patient with MRS associated with aseptic meningitis due to VZV who had no typical symptoms of meningitis or VZV infection.

\section{Case presentation}

A 58-year-old man with no particular past medical history had fever of $38{ }^{\circ} \mathrm{C} 11$ days before admission. Dysesthesia of both the lower limbs and acute urinary 
retention were observed in the same day. Although the fever improved after a few days, 7 days before admission, the patient developed urinary retention 7 days before admission, which required intervention by a urologist. As urinary drainage and oral administration of silodosin, urapidil, baclofen, and distigmine did not improve the patient's condition, however, a spinal cord lesion was suspected and he was referred to our institution.

On systemic review during a medical examination at our institution, bilateral lower limb dysesthesia, dysuria, and constipation were present, whereas fever, headache, nausea, vomiting, and rash were absent.

He was fully conscious, and with pulse rate, temperature, blood pressure, and respiratory rate of 117 beats/ min, $36.5{ }^{\circ} \mathrm{C}, 153 / 110 \mathrm{mmHg}$, and 15 breaths $/ \mathrm{min}$, respectively. A physical examination did not reveal any rash, or any other obvious abnormal findings while neurological examination was negative for Jolt accentuation, no nuchal rigidity, and Kerning's and Brudzinski's signs. However, the Babinski reflexes wore positive bilaterally, and he had right patellar tendon hyperreflexia and positive Romberg and Mann tests. In addition, he had urinary retention and constipation, and decreased anal sphincter reflex, a reduction in vibratory sensation in both lower limbs and dysesthesia in parts of the lower limbs as illustrated in Fig. 1. There were no other abnormalities neurologic examination. The Laboratory test results on presentation are shown in Table 1. The abnormalities included relative neutrophilia, and elevated levels of D-dimer, procalcitonin, lactic dehydrogenase, blood urea nitrogen and creatinine.

No abnormalities were noted in urinalysis. Abdominal computed tomography (CT) revealed urinary and fecal retentions, but there was no space-occupying lesion in the pelvis nor a lumbar spinal canal stenosis. No abnormalities were observed in the spine on magnetic resonance imaging (MRI), but cranial contrast-enhanced MRI showed meningeal thickening (Fig. 2).

Because the cranial MRI indicated meningitis and MRS was suspected to be the cause of his acute urinary

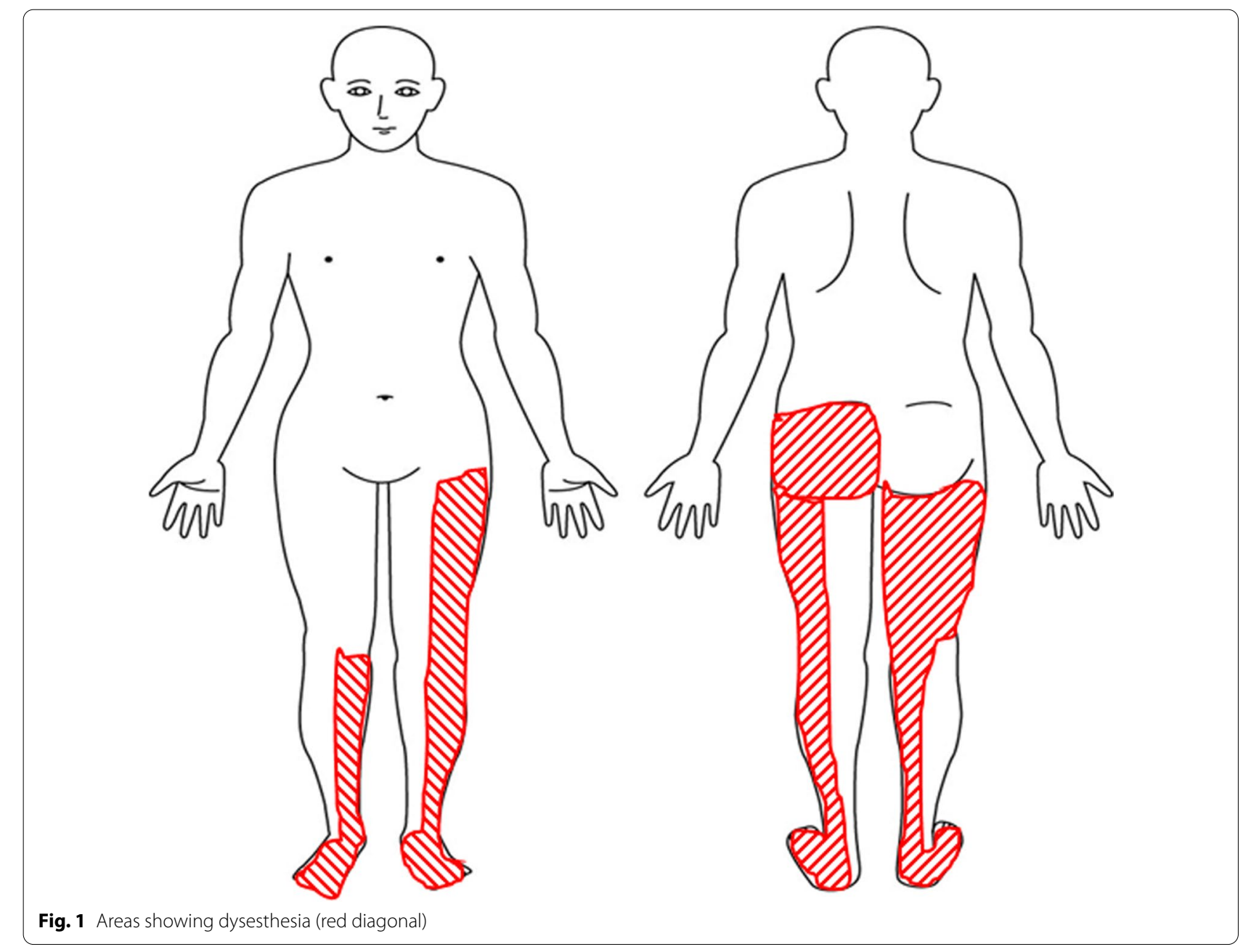


Table 1 Laboratory data on admission

\begin{tabular}{|c|c|c|}
\hline Parameter & Recorded value & Standard value \\
\hline White blood cell count & $7920 / \mu \mathrm{L}$ & $4500-7500 / \mu \mathrm{L}$ \\
\hline Neutrophils & $81.4 \%$ & $42-74 \%$ \\
\hline Lymphocytes & $13.5 \%$ & $18-50 \%$ \\
\hline Monocytes & $4.7 \%$ & $1-10 \%$ \\
\hline Hemoglobin & $16.8 \mathrm{~g} / \mathrm{dL}$ & $11.3-15.2 \mathrm{~g} / \mathrm{dL}$ \\
\hline Platelet count & $335 \times 10^{3} / \mu \mathrm{L}$ & $130-350 \times 10^{3} / \mu \mathrm{L}$ \\
\hline Prothrombin time/international normalized ratio & 1.02 & $0.80-1.20$ \\
\hline Activated partial thromboplastin time & $27.9 \mathrm{~s}$ & $26.9-38.1 \mathrm{~s}$ \\
\hline D-dimer & $2.1 \mu \mathrm{g} / \mathrm{mL}$ & $<1.0 \mu \mathrm{g} / \mathrm{mL}$ \\
\hline C-reactive protein & $0.03 \mathrm{mg} / \mathrm{L}$ & $\leq 0.60 \mathrm{mg} / \mathrm{dL}$ \\
\hline Procalcitonin & $0.97 \mathrm{ng} / \mathrm{mL}$ & $\leq 0.05 \mathrm{ng} / \mathrm{mL}$ \\
\hline Total protein & $8.0 \mathrm{~g} / \mathrm{dL}$ & $6.9-8.4 \mathrm{~g} / \mathrm{dL}$ \\
\hline Albumin & $4.4 \mathrm{~g} / \mathrm{dL}$ & $3.9-5.1 \mathrm{~g} / \mathrm{dL}$ \\
\hline Total bilirubin & $1.2 \mathrm{mg} / \mathrm{dL}$ & $0.2-1.2 \mathrm{mg} / \mathrm{dL}$ \\
\hline Aspartate aminotransferase & $26 \mathrm{U} / \mathrm{L}$ & $11-30 \mathrm{U} / \mathrm{L}$ \\
\hline Alanine aminotransferase & $37 \mathrm{U} / \mathrm{L}$ & 4-30 U/L \\
\hline Lactase dehydrogenase & $190 \mathrm{U} / \mathrm{L}$ & $109-216 \mathrm{U} / \mathrm{L}$ \\
\hline Creatine kinase & $44 \mathrm{U} / \mathrm{L}$ & $40-150 \mathrm{U} / \mathrm{L}$ \\
\hline Blood urea nitrogen & $35.8 \mathrm{mg} / \mathrm{dL}$ & $8-20 \mathrm{mg} / \mathrm{dL}$ \\
\hline Creatinine & $1.50 \mathrm{mg} / \mathrm{dL}$ & $0.63-1.03 \mathrm{mg} / \mathrm{dL}$ \\
\hline Sodium & $138 \mathrm{mEq} / \mathrm{L}$ & $136-148 \mathrm{mEq} / \mathrm{L}$ \\
\hline Potassium & $4.4 \mathrm{mEq} / \mathrm{L}$ & 3.6-5.0 mEq/L \\
\hline Chloride & $100 \mathrm{mEq} / \mathrm{L}$ & 98-108 mEq/L \\
\hline Glucose & $117 \mathrm{mg} / \mathrm{dL}$ & $70-109$ mg/dL \\
\hline Hemoglobin A1c & $5.8 \%$ & $5.6-5.9 \%$ \\
\hline
\end{tabular}

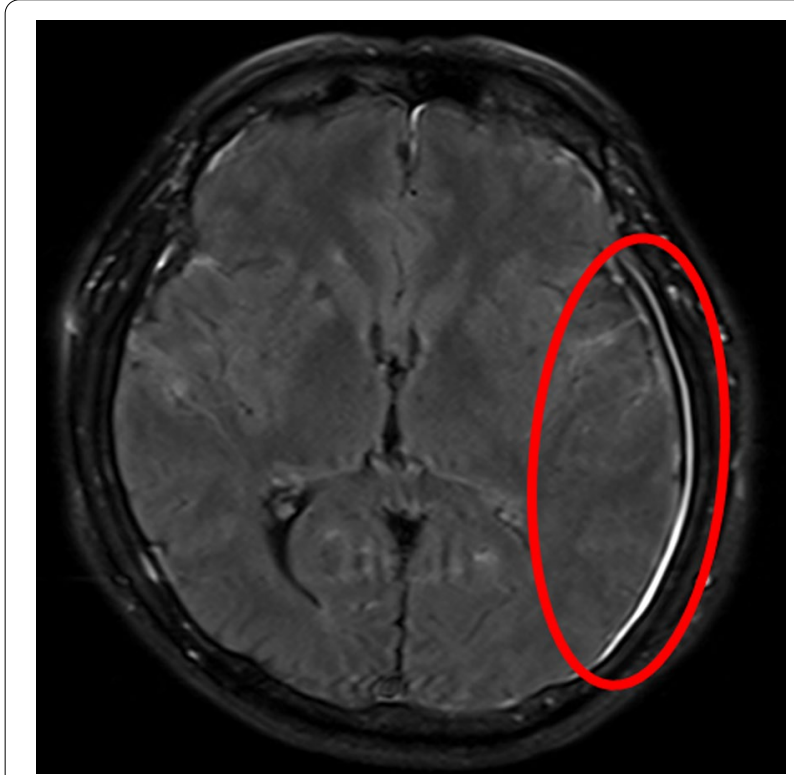

Fig. 2 Head contrast-enhanced MRI showing meningeal thickening and contrast enhancement (red circle) retention, his cerebrospinal fluid was examined for confirmation of the diagnosis. The results were as follows: cell count of $232 / \mu \mathrm{L}$ (mononuclear cells $227 / \mu \mathrm{L}$, polymorphonuclear cells $5 / \mu \mathrm{L})$, protein level of $331 \mathrm{mg} /$ $\mathrm{dL}$, sugar level of $69 \mathrm{mg} / \mathrm{dL}$ (47.6\% of the simultaneous blood glucose level of $145 \mathrm{mg} / \mathrm{dL}$ ), and adenosine deaminase concentration of $14.5 \mathrm{U} / \mathrm{L}$. Furthermore, the CSF was positive for VZV DNA, but negative for cryptococcal Ag, and general bacterial, and mycobacterium cultures. The titers of various viruses in the serum are shown in Table 2. The elevated VZV IgM level indicated acute phase infection, while the high VZV IgG level indicated a reactivation of VZV. Elevated EpsteinBarr virus viral capsid antigen IgG and Epstein-Barr virus nuclear antigen IgG indicated past Epstein-Barr virus infection, while the negative Epstein-Barr virus IgM ruled-out acute Epstein-Barr virus infection.

The final diagnosis was MRS owing to aseptic meningitis due to VZV. After the diagnosis, he was given intravenous acyclovir at a dose of $625 \mathrm{mg}$ every $8 \mathrm{~h}$ for 14 days. The subsequent course is shown in Fig. 3. The symptoms gradually improved, and management 
Table 2 Titers of various viruses in the serum

\begin{tabular}{lll}
\hline Parameter & Recorded value & standard value \\
\hline Human immunodeficiency virus antigen antibody & $(-)$ & $(-)$ \\
Hepatitis B surface antigen & $(-)$ & $(-)$ \\
Hepatitis C virus antibody & $(-)$ & $(-)$ \\
Rapid plasma reagent & $(-)$ & $(-)$ \\
Treponema pallidum latex agglutination & $(-)$ & $(-)$ \\
EB-VCA IgM & 0.0 EIA value & $<0.4$ EIA value \\
EB-VCA IgG & 7.4 EIA value & $<0.4$ EIA value \\
EBNA IgG & 4.7 EIA value & $<0.4$ EIA value \\
HSV IgM & 0.15 EIA value & $<0.7$ EIA value \\
HSV IgG & $<2.0$ EIA value & $<2.0$ EIA value \\
VZV IgM & 8.24 EIA value & $<0.8$ EIA value \\
VZV IgG & 128.0 EIA value & $<2.0$ EIA value \\
Mumps virus IgM & 0.04 EIA value & $<0.7$ EIA value \\
Mumps virus IgG & 2.6 ElA value & $<2.0$ EIA value \\
\hline
\end{tabular}

EB-VCA Epstein-Barr virus viral capsid antigen, EBNA EBV Epstein-Barr virus nuclear antigen, $H S V$ herpes simplex virus, VZV varicella zoster virus, EIA enzyme immunometric assay

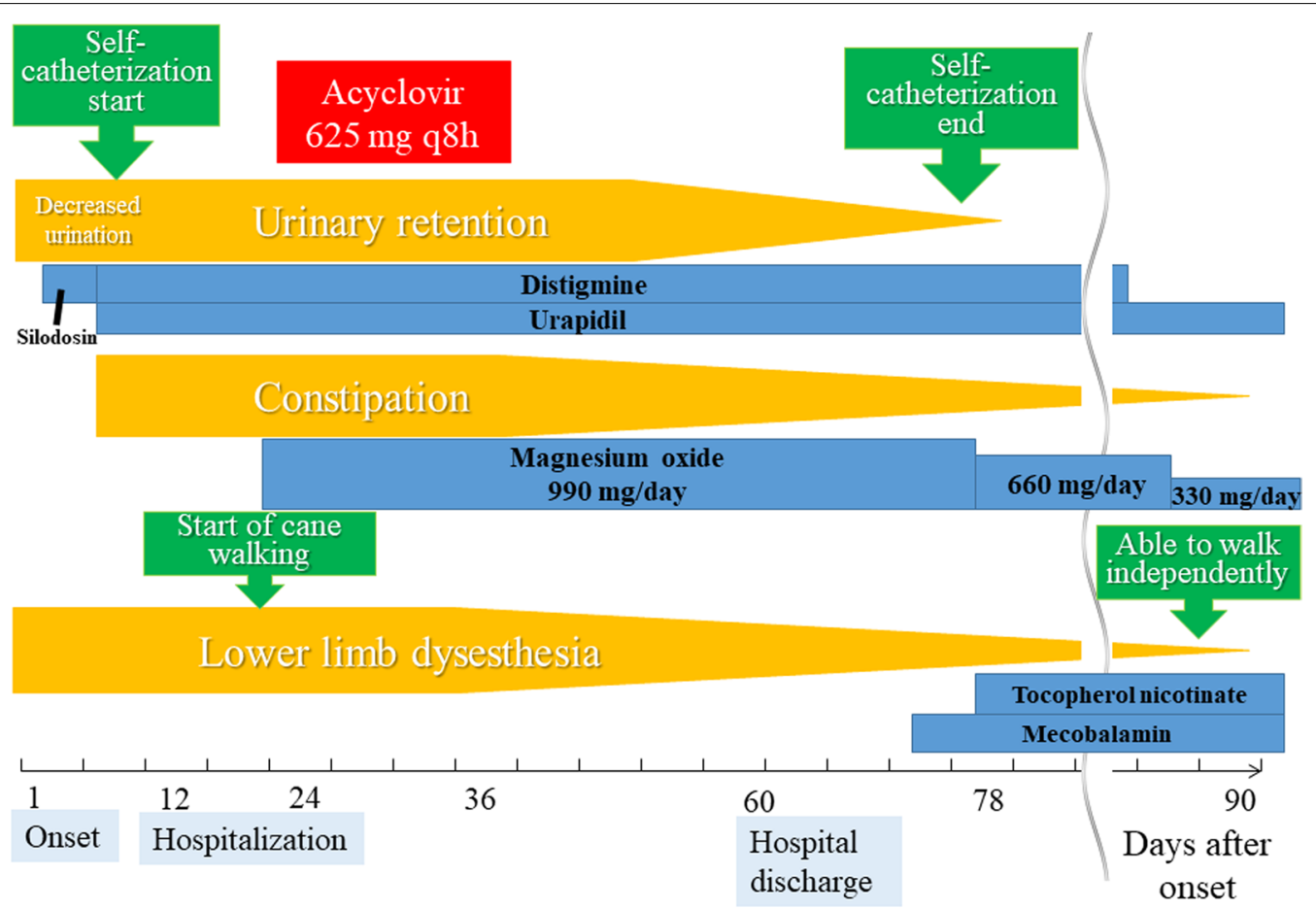

Fig. 3 Clinical course of symptoms

with oral medications (distigmine, urapidil, magnesium oxide) became feasible.

The medications for dysuria and dyschezia have been discontinued, and 2 years have passed since the onset of MRS. No sequelae have been observed, and the patient is being followed up.

\section{Discussion and conclusions}

Except for fever, no findings indicative of meningitis were observed on presentation, and diagnosing the condition as VZV meningitis without a rash was difficult.

MRS is a rare condition that presents with complications of aseptic meningitis and dysuria [2]. Furthermore, 
MRS due to VZV is rare $[2,4,5,7,10-12]$. To the best of our knowledge, only one previous case of VZV meningitis without a rash that led to MRS has been reported [5]. The mechanism of MRS is presumed to include spinal shock owing to meningeal irritation, inflammation of upper motor neurons of the spinal cord, direct viral entry, and onset of acute disseminated encephalomyelitis after viral infection [13].

No rash was not observed before and after the onset. A previous study reported that skin findings were not observed in $40 \%$ of patients with meningoencephalitis caused by VZV [6]. Thus, the possibility of VZV should be considered in the differential diagnosis of aseptic meningitis, despite the absence of a rash. If urinary retention without an identifiable cause is present, MRS due to aseptic meningitis should be considered in the differential diagnosis, and cerebrospinal fluid should be examined, despite a lack of signs of meningitis.

In conclusion, meningitis due to VZV without a rash is possible, as is meningitis without specific signs and symptoms. Therefore, despite the absence of symptoms or signs suggestive of meningitis, MRS owing to aseptic meningitis, including VZV, should be considered in the differential diagnosis of acute urinary retention.

\section{Abbreviations}

CT: Computed tomography; Ig: Immunoglobulin; MRI: Magnetic resonance imaging; MRS: Meningitis retention syndrome; VZV: Varicella zoster virus.

\section{Acknowledgements}

None.

\section{Authors' contributions}

TK managed the case, and prepared and revised the manuscript. KG and AK assisted with the preparation and revision of the manuscript. All co-authors approved the final manuscript as submitted and agree to be accountable for all aspects of the work. All co-authors take full responsibility for the integrity of the study and the final manuscript. All authors read and approved the final manuscript.

\section{Funding}

Not applicable.

\section{Availability of data and materials}

All data generated or analyzed during this study are included in this published article.

\section{Declarations}

\section{Ethics approval and consent to participate}

Ethics approval and consent to participate does not apply, because this is a case report. The ethics committee of Hyogo Prefectural Tamba Medical Center exempted protocols from ethics because it not a research study. Consent to participate does not apply.

\section{Consent for publication}

Written informed consent was obtained from the patient for the publication of this case report and accompanying images. A copy of the written consent is available for review by the Editor of this journal.

\section{Competing interests}

The authors declare that they have no competing interests.

\section{Author details}

${ }^{1}$ Department of Internal Medicine, Hyogo Prefectural Tamba Medical Center, Tanba, Japan. ${ }^{2}$ Division of Community Medicine and Career Development, Kobe University Graduate School of Medicine, 2-1-5, Arata-cho, Hyogo-ku, Kobe, Hyogo 652-0032, Japan.

Received: 1 June 2020 Accepted: 14 September 2021

Published online: 23 September 2021

\section{References}

1. Choong S, Emberton M. Acute urinary retention. BJU Int. 2000;85:186-201.

2. Sakakibara R, Kishi M, Tsuyusaki Y, Tateno A, Tateno F, Uchiyama T, et al. "Meningitis-retention syndrome": a review. Neurourol Urodyn. 2013;32:19-23.

3. Gregušová A, Klézl P, Mašková V, Smišková D, Pícha D, Malikova H. Acute urinary retention in aseptic meningitis: meningitis-retention syndrome. Neuro Endocrinol Lett. 2019;40:166-8.

4. Erol B, Avci A, Eken C, Ozgok Y. Urinary retention, erectile dysfunction and meningitis due to sacral herpes zoster: a case report and review of the literature. Urol Int. 2009:82:238-41.

5. Abe M, Araoka H, Kimura M, Yoneyama A. Varicella zoster virus meningoencephalitis presenting with Elsberg syndrome without a rash in an immunocompetent patient. Intern Med. 2015;54:2065-7.

6. Koskiniemi M, Piiparinen $\mathrm{H}$, Rantalaiho T, Eränkö P, Färkkilä M, Raiha K, et al. Acute central nervous system complications in varicella zoster virus infections. J Clin Virol. 2002;25:293-301.

7. Takeshima S, Shiga Y, Himeno T, Tachiyama K, Kamimura T, Kono R, et al. Clinical, epidemiological and etiological studies of adult aseptic meningitis: report of 11 cases with varicella zoster virus meningitis. Rinsho Shinkeigaku. 2017;57:492-8 (Article in Japanese).

8. Attia J, Hatala R, Cook DJ, Wong JG. The rational clinical examination. Does this adult patient have acute meningitis? JAMA. 1999;282:175-81.

9. Steiner I, Budka H, Chaudhuri A, Koskiniemi M, Sainio K, Salonen O, et al. Viral meningoencephalitis: a review of diagnostic methods and guidelines for management. Eur J Neurol. 2010;17:999-e57.

10. Dinh A, Salomon J, Schoindre Y, Mathez D, Denys P, Durand MC, et al. Acute urinary retention due to viral coinfections (HIV, HBV, VZV). J Int Assoc Phys AIDS Care (Chic). 2010;9:20-2.

11. Saito H, Ebashi M, Kushimoto M, Ikeda J, Egashira F, Yamaguchi S, et al. Elsberg syndrome related to varicella zoster virus infection with painless skin lesions in an elderly woman with poorly controlled type 2 diabetes mellitus. Ther Clin Risk Manag. 2018;14:1951-4.

12. Kim TW, Whang JC, Lee SH, Choi JI, Park SM, Lee JB. Acute urinary retention due to aseptic meningitis: meningitis-retention syndrome. Int Neurourol J. 2010;14:122-4.

13. Krishna A, Devulapally P, Ghobrial I. Meningitis retention syndrome. J Community Hosp Intern Med Perspect. 2012. https://doi.org/10.3402/ jchimp.v2i1.15761.

\section{Publisher's Note}

Springer Nature remains neutral with regard to jurisdictional claims in published maps and institutional affiliations. 